\title{
HOW HUMOUR MAKES A DIFFERENCE
}

\author{
Seppo Knuuttila
}

\begin{abstract}
In this article I shall look into how the use of examples in humour research has both manifested and controlled the ongoing discussion. I will also briefly ponder, what the often used discussion-raising examples of humour have signified regarding folklore and cultural history.

I also intend to comment on Arvo Krikmann's discussion on the connections and differences between humour and figurative speech. Through examples, attempts will be made to search for the obscure meanings that in jokes are left unsaid, but that are apparently essential for the humorous impact. Producing gaps in the plots can even be considered one of the forms of expression of jokes.

In closing, a few words and images on humour in visual contemporary folk art that have attracted a lot of interest in Finland for over the past ten years. With a few examples, I will shed light on the relationship between the target and the source.
\end{abstract}

Key words: articulation, humour, trope, unsaid, use of examples

Henri Bergson (1998 [1900]) ends his notorious essay on Laughter with a metaphor of sea foam condensing into a few salty drops. "Laughter, also, is froth with a saline base," he writes. "Like froth, it sparkles. It is gaiety itself. But the philosopher who gathers a handful to taste may find that the substance is scanty, and the after-taste bitter." Bergson is apparently referring to the doctrine of mixed emotions. In the history of Western metaphysics, the pure and unsubstantial is portrayed as having always existed before the mixed and impure. According to René Descartes joy is a pure emotion that does not make a person burst out laughing but can only make one enjoy the humour when it is moderate, while mixed with a certain amount of surprise or anger. According to this doctrine, tragedy is a manifestation of pure emotion, while in comedy the emphasis is on mixed, incongruent elements.

The research of humour, the comic and laughter has always included the premise of ambivalence, paradox and incongruity. Arvo Krikmann has also pondered this hypothesis in his several writings on the subject of humour, the penetrating theme being that humour can only be understood and interpreted in relation to another entity, context, figurative speech, tropes, politics, sex, ethnicity. Krikmann sides with Bergson and many other critical scholars in 
that humour's general theories do not convince him of their comprehensive power of explanation. (Krikman 2006, 2008, 2009)

Krikmann is also of the opinion that joke tradition in contemporary welfare societies is undergoing a relatively rapid degeneration, and the same trend is also becoming more and more apparent in the post-socialist countries. Perhaps it would seem, while observing contemporary media, that the quantity of humour obscures its quality, but similar tendencies of humour's degeneration have seemingly already been observed by aestheticians a long time ago. It has been said of sense of humour, among other things, that it only comes to full bloom in maturity, when a person has acquired enough life experience to be able to discriminate between serious and non-serious matters. Personally, though, I have met children and young people with quite a good sense of humour.

In the following, I shall first look into how the use of examples in humour research has both manifested and controlled the ongoing discussion. Something profound seems to be at play in the question of what makes a presentation, an image or a text humorous. I will also briefly ponder what the often used discussion-raising examples of humour have signified regarding folklore and cultural history. In addition, I intend to comment on Krikmann's discussion on the connections and differences between humour and figurative speech; through examples, I will be searching for the obscure meanings that in jokes are left unsaid, but that are apparently essential for the humorous impact. These dimensions of "social logic" have held a central position especially in the sociological and anthropological study of humour. It is thus easy to join Krikmann in wishing that "cognitive theorists of figurative language and humour should strive for closer integration with scholars of the cultural and social aspects of human communication, for the greater 'ecological validity' of the results they are obtaining” (Krikmann 2009). And vice versa, I would like to add a few words and images on humour, in visual contemporary folk art, that have attracted a lot of interest in Finland over the past ten years. With a few examples, I will shed light on the relationship between the target and the source, and try to guess which one of these wins.

\section{CATS AND DOORS AS SHIFTERS}

The most utilized exemplary sentence in philosophy is "the cat is on a mat". As a claim about truth it is adequate only if the cat actually is on the mat. But the sentence can also have been made up to show how the correspondence theory of truth functions. Or the example can be quoted from some literary text or 
speech, in which case its relationship with reality, of course, changes. In the research of humour, examples have been used throughout its history. Sometimes it has been the case that discussions have begun to repeatedly use some artificial or condensed examples, in order to discuss various theoretical questions (see Hansson 2006).

Contemporary scholars of humour are well familiar with the example launched by Victor Raskin (1985), where the patient asked in his bronchial whisper: "Is the doctor at home?" "No," doctor's young and pretty wife whispered in reply, "Come right in." In addition to Raskin himself having analyzed this text several times, it has become a kind of a touchstone of the script-based semantic theory of humour for already over twenty years. Some say it has already been analyzed as an example ad nauseam. In a short rerun: the joke begins with a patient/doctor-script, which then suddenly turns into a lover script, when the young pretty woman whispers "come right in". This kind of a condensed example emphasizes namely the incompatibility of the scripts and the resulting disinformation. The target of laughter is, I suppose, the woman, a young, beautiful adulteress.

In the early 20th century, and earlier, the question of what leads into a humorous impression was discussed in the light of a slightly different example. The example was as follows: A man hears sounds from his closet and thinks there is a cat. But when he opens the door, he finds his mother-in-law in the closet. Commenting on the example, the Finnish aesthetician Yrjö Hirn (1914) has considered it to be artificial, exclaiming "The things a learned man's imagination can come up with!" The two-way reading of this example has been pondered especially by Theodor Lipps in his book Komik und Humor (2010 [1898]): the comical impression is not, according to Lipps and Hirn, brought about by the expected small turning big, but by a human temporarily being compared to a cat.

There are, then, two identifiable scripts in the example, those of the cat and the parent-in-law, which, when mixed together, produce a comical impression. Because the examples are condensed, there does not seem to be a point in contemplating whether the potential target would be the mother-in-law or the cat. In fact the discussion has been about the somewhat similar reading of both contemporary and old examples, only the terms and the contexts of interpretation have changed from aesthetics to semantics, linguistics, and moved towards different contextual models. The closet-example is typically linked to the superiority view and theory, which still has presenters and supporters, for example when discussing malicious pleasure.

It is clear that the questions on humour and the comical will not be solved through examples, even if these can illuminate different interpretations and 
theories. It can in fact be the case that the more the data from various eras and cultures is analyzed, the harder it is to say what the separate examples express and what exactly do they exemplify. When Arvo Krikmann writes of having read the types of folktales by Aarne, Thompson and Uther, jokes on Nasreddin, the tales of Aesop and the texts of the Philogelos collection, he states "I did not obtain any substantially new insights into the "history of the punch line', but I definitely completely lost my hitherto perception what a punch line is, and my faith in its strictly bivalent nature." (Krikmann 2008) A problem with the formal theories of humour has generally been their narrowness, even though it has been tried to apply this universally. On the other hand, the General Theory of Verbal Humour (GTVH, see Attardo \& Raskin 1991) is so wide that it can be easily applied to several kinds of texts, including detective stories, science fiction, horror stories, and fairy tales and myths that do not a priori contain humour.

In further contemplation of how an element in a humorous text splits the imaginary and the perceived into two contradicting scripts, it is worthwhile to pay attention to what aspect of the story is not communicated explicitly to the receivers, what part of the message is left undelivered (i.e. the whisper or rustling behind the door in the aforementioned example). The door acts as the facilitator of communication for example in the joke ATU 1419H, "A wife has a lover who visits her regularly when her husband is away. One time her husband stays home unexpectedly. When the lover knocks on the door, the wife sings a lullaby in despair in which she warns him and tells him to go away." Many tales/jokes of ATU about infidelity are present as motifs, for example, in the Decameron collection, and also in the structure of what is not communicated to some party, often the target of the humorous presentation, remains the same. This method of producing comic art is still productive.

Instead of the previous condensed examples I will offer a different one in which a door is also central but otherwise, the content of the example is absurd. According to Uwe Wirth, in the next joke example our expectations as interpreters get disappointed in a funny way, and "our normal understanding, our lumen culturale gets irritated" (Wirth 2001).

A man - apparently an encyclopaedia salesman - walks up to the door of an apartment and rings the bell. Man: "Burglar!" (longish pause while he waits, then he rings again). "Burglar!" (a woman appears at the other side of the door). The woman: "Yes?" Man: "Burglar, madam." Woman: "What do you want?" Man: "I want to come in and steal a few things, madam." Woman: "Are you an encyclopaedia salesman?" Man: "No madam, I'm a burglar. I burgle people." Woman: "I think you're an encyclopaedia salesman." Man: "Oh I'm not, open the door, let me in please." Woman: "If I let you in, you'll sell me encyclopae- 
dias?" Man: "I won't, madam. I just want to come in and ransack the flat. Honestly." Woman: "You promise no encyclopaedias?" Man: "None at all." Woman: "All right," and opening the door "You'd better come in then." (Man enters through the door). Man: "Mind you I don't know whether you've really considered the advantages of owning a really fine set of modern encyclopaedias ... (he pockets valuables) You know, they really can do you wonders." (Monty Python's Flying Circus 1969)

The masquerade of covering and uncovering is, in the light of humour, the recognition and Gelassenheit of the paradox of being. I think the Finnish aesthetician Aarne Kinnunen (1994) means quite the same, in writing: "Particular to humour is not the absurdity or logical paradoxes or other dichotomies strongly attached to each other, but the very lack of a conceptual or understandable connection between the components." Producing gaps in the plots, enthymemes in one word, can even be considered one of the forms of expression of jokes. On the other hand, humorous stories make us think of articulations that would otherwise hardly cross our minds. This kind of uncovering is, according to Freud, a central function of obscene jokes.

In the end of the paper of "“ATU jokes": old and abandoned" (2008), Krikmann gives a few examples from the Philogelos collection "without ATU parallels". One of them came back to me while reading Finland's main newspaper (Helsingin Sanomat 8.8.2009). The Philogelos example is as follows: "Running into a poindexter, a friend said: "I congratulate you on the birth of your son." To which he replied: "Yes, thanks to all my friends."' The story in the newspaper (slightly abbreviated) was: a well-known Finnish ice hockey player had just had a son. When he was congratulated, being a modest man he replied: "Thank you, thank you, but the thanks should go to the whole team." This is a slight category mistake or miscalculation, productive in producing humour in both earlier and contemporary times.

\section{THE ROLE OF THE UNSAID AND THE SPEECH FIGURES}

The research of humour often seems to be stuck in a technical assumption according to which all expressions of humour, along with their meanings, would be somehow static and thus countable texts (jokes, anecdotes, caricatures, comedies, farces). The anthropologist Gregory Bateson (1985) points out, however, that it is not possible to read jokes out of an ink blot, because it does not include any, but a person of a humorous approach can see in the blot's - or whatever - comical forms, characters, expressions and so on. According to Bateson there is always an experiential component in the formation of schizo- 
phrenia, falling in love, intoxication, religious euphoria, humour and phenomena of the art world related to these; the element connecting them is, according to Bateson, trans-contextual:

It seems that both those whose life is enriched by trans-contextual gifts and those who are impoverished by trans-contextual confusions are alike in one respect: for them there is always or often a "double take." A falling leaf, the greetings of a friend, or a "primrose by the river's brim" is not "just that and nothing more." (Bateson 1985)

Important from the perspective of humorous communication are the implicit, unspoken premises (enthymemes) that create gaps in the narrative and sometimes make it enigmatic. In addressing the relationship between anecdotes and their impact, Ted Cohen (1983) gives an example of which he claims to be particularly fond:

It is about an old couple living far away in a remote region, neither of which has ever seen a mirror. One day the man finds a piece of a mirror. He takes it up to his attic, carefully polishes it and gazes long into it. Finally he exclaims: "Father!" During the weeks that follow he often goes up to the attic and spends many an hour there. His wife begins to get worried at the way he is behaving and doubts his fidelity. One day while he is out she goes up to the attic and immediately spots the mirror. She gazes into it and goes back downstairs, muttering to herself: "What a relief! My old man would never fall for such a wrinkled old woman. She looks just like my mother."

The implicit premise of this example, and the comic condition, is that the old ones do not know what they look like. The significant thing from the point of narrative strategy is that neither says a word to the other about the mirror (or indeed about anything else in this text). According to the logical mechanism of the anecdote, the discussion they do not have is important as regards both the humorous effect and the preservation of their marriage. The communicative context is constructed out of the fact that both know of the mirror's existence, but the man does not know that his wife knows.

Tony Veale (2004) has contemplated the problem regarding the placement of humour and the preceding solutions in a critical manner. According to him, other and non-humorous interpretations can be placed alongside the humorous interpretation. The example of the bronchial patient could be read, for instance, as the madam simply asking the patient to step in to wait for the doctor to return (see also de Mey 2005). It is quite easy to imagine how the recipients of the mirror joke may have contemplated other chances: why didn't 
the man tell his wife about the mirror he had found and the other way around? The answer from the folkloristic point of view is quite simple in all those cases: because then there would be no story. The anecdote itself constructs a textual context in which the unsaid becomes meaningful. According to Bateson, the letter that is not written, the apology that is never made, or the food that is not given to the cat can be effective messages, because in some contexts zero may be significant (Bateson 1979: 56).

In all the preceding examples, factual, consented or literary, it is possible to locate the unsaid gap between the source and the target, or as Krikmann (2006) puts it, between the first isotopy and the second isotopy. What is left unsaid, or is otherwise not communicated, is however a meaningful element in the joke. According to Marlene Dolitsky, "humour conveyed through language is located at the point of the unsaid, i.e. the unstated presuppositions, inferences, references, associations and interpretations" (Dolitsky 1983). Extrapolating from her interpretation it can be said that humour through figurative speech exists in the hearers' focus bouncing back and forth between the said and the unsaid.

Therefore, this is very close to the similarities Krikmann has perceived in between figurative speech, especially metaphor, and humour:

Both metaphors and jokes cross the borders, reach the obstacle, backtrack to the left, look around, take something along; but when a metaphor returns to the right and once more to the left and remains, a joke returns from the left backtracking to the right and remains. (Krikmann 2009)

Elsewhere I have contemplated what the consequences are if an anachronism, as a dislocation of time, is interpreted as a figure of speech (i.e. a trope) instead of a simple mistake. A trope in this context means an articulation or a linkage, in which two (or more) utterances combine to form a so-called third meaning. Anachronism differs from the main tropes in that it always manipulates the course and structures of time. When anachronism is examined as a trope, like metaphor, metonym, etc., then it can be seen as a consciously chosen means of expression through which relationships between the past, present and future are organized, moving in time as metaphors and jokes in texts.

Anachronism is also a popular form of comedy. The Finnish playwright Alexis Kivi wrote the following dialogue between the bridegroom Esko and the matchmaker Mikko in his play Nummisuutarit (Cobblers on the Heath 1865). A bit earlier, Esko had knocked over a table and broken a window in the wedding hall, and they must now mention this to Esko's mother but they do not want to tell the truth, and lying is not appealing. 
Mikko: "They'll ask me what happened, and I'll have to tell all, and, sad to say, I'll have to end my tale with your vandal's work at Karri's - yes, Esko, I'll have to mention the overturned table, the smashed windows and the violin."

Esko: "No need to tell all that, just say we left Karri's a little before I overturned the table."

Mikko: "All right, you play your mother's role and ask me when we left Karri's."

Esko: "Mikko Lightfoot, when did you and my boy Esko leave Karri's?"

Mikko: "We left just before Esko overturned the dinner table."

Esko: "Mikko, this is no time for jesting. Say we left just as wedding guests were leaving for the hayfield."

Mikko: "Teach me not to lie."

\section{ARTICULATION AND SOME MORE EXAMPLES}

In accepting the idea that several figures of speech and humorous presentations link the source and the target, or consecutive isotopes to each other in various ways, it is worth asking what kind of methodical constructions produce "the third meanings". Most obviously, this can be found in articulation theory, defined for instance by Stuart Hall (Grossberg 1986) as "the form of the connection that can make a unity of two different elements, under certain conditions. It is a linkage which is not necessary, determined, absolute and essential for all the time". Or, as Lawrence Grossberg (1992) puts it, "Articulation links this practice to that effect, this text to that meaning, this meaning to that reality, this experience to those politics".

Articulation theory requires a subject, which connects things, and a recipient, who recognizes the articulation in question. In this sense the theory is particularly suitable for studying the humour of folk art. When the Finnish artist and humorist Martti Innanen says that "Others do not see a fur hat on the head of each Finn, but I do", he links the Finn and the fur hat in a way that in his paintings generates a combination recognized comical at least by Finns themselves. This can be seen, for example, in his work of art "The Framed Nation", which can also be studied as an example of the reception process of a humorous performance.

What is typical of humorous works of folk art (besides scale manipulation) is the surprising and often also ideological articulation between material and content. The Martti Hömppi's orchestra-statue is manufactured of unpainted leftover planks. The title of the work is the Trio of Empty Heads and it depicts three well-known Finnish politicians; the heads of the musicians are made of 
birdhouses. The artist's aim is thus to point out that the politicians are unable to take proper care of the people's problems, their speech being full of "empty rhetoric" (see Knuuttila 2009).

The humour is more of a tender nature in another work of art by Martti Hömppi, depicting the current Finnish president Tarja Halonen and her husband Pentti Arajärvi. While it is also constructed of planks, it has been painted in the Finnish colours, blue and white. The wife pushes the husband sitting in the cart, i.e. things are not as they should be. Maybe the arrangement reminds us of the anecdotes of the world upside down, in which women do men's tasks, and men the women's.

\section{IN LIEU OF A CONCLUSION}

It is easy to agree with Arvo Krikmann about the fact that, in addition to old and new formal theories, the research of humour requires cross-disciplinary discussion as much as any progressive research. The perspective of folklore and cultural history can illuminate the temporal phases of the materials, for example what kinds of humorous motifs have been known for centuries, if not for millennia, and to which kinds of texts they have been attached to in different eras. The relations of both verbal and visual humour to other means of expression are as informative.

After Gregory Bateson's famous formation, to which the headline of this article also tributes, "a difference which makes a difference is an idea. It is a 'bit', a unit of information" (Bateson 1985). So the humour which makes a difference is a unit of information like tropes and other forms of figurative speech being in one context serious, in other humorous. Liisi Laineste, a former student of Arvo Krikmann, has come up with a use for the salt left on Bergson's palm from the froth of humour, namely "the idea of topical jokes is to point the need to take social reality with a grain of salt" (Laineste 2008).

\section{REFERENCES}

Attardo, Salvatore \& Raskin, Victor 1991. Script Theory revis(it)ed: joke similarity and joke representation model. Humor: International Journal of Humor, Vol. 4, No. 3/4, pp. 293-374.

ATU = Uther, Hans-Jörg 2004. The Types of International Folktales. A Classification and Bibliography, Based on the System of Antti Aarne and Stith Thompson. Editorial staff: Sabine Dinslage, Sigrid Fährmann, Christine Goldberg, Gudrun Schwibbe. 1: Animal Tales, Tales of Magic, Religious Tales, and Realistic Tales, with an Introduction; 2: Tales of the Stupid Ogre, Anecdotes and Jokes, and 
Formula Tales; 3: Appendices. (FF Communications 284/285/286). Helsinki: Suomalainen Tiedeakatemia.

Bateson, Gregory 1979. Mind and Nature. A Necessary Unity. Toronto: Bantam Books. Bateson, Gregory 1985 [1972]. Steps to an Ecology of Mind: Collected Essays in Anthropology, Psychiatry, Evolution, and Epistemology. New York: Ballantine Books.

Bateson, Gregory \& Bateson, Mary Catherine 1987. Angels Fear. An Investigation into the Nature and Meaning of the Sacred. New York: Rider.

Bergson, Henri 1998 [1900]. Laughter: An Essay on the Meaning of Comic. http:// www.authorama.com/laughter-15.html, last accessed on 20 Nov 2010.

Cohen, Ted 1983. Jokes. In: E. Shaper (ed.) Pleasure, Preference, and Value. Studies in Philosophical Aesthetics. Cambridge: Cambridge University Press, pp. 120-136.

de Mey, Tim 2005. Tales of the Unexpected: Incongruity-Resolution in Humor Comprehension, Scientific Discovery and Thought Experimentation. Logic and Logical Philosophy, Vol. 14, pp. 69-88.

Dolitsky, Marlene 1983. Humor and the Unsaid. Journal of Pragmatics, Vol. 7, No. 1, pp. 39-48.

Grossberg, Lawrence 1986. On Postmodernism and Articulation. Journal of Communication Inquiry, Vol. 10, No. 2, pp. 45-60.

Grossberg, Lawrence 1992. We Gotta Get Out of This Place: Popular Conservatism and Postmodern Culture. New York: Routledge.

Hansson, Sven Ove 2006. Editorial: Condensed Examples in Philosophy. Theoria, Vol. 72, No. 2, pp. 97-99.

Hirn, Yrjö 1914. Esteettinen elämä. Helsinki: Otava.

Kinnunen, Aarne 1994. Huumorin ja koomisen keskeneräinen kysymys. Porvoo \& Helsinki \& Juva: Werner Söderström Osakeyhtiö.

Knuuttila, Seppo 2009. Self-made life, humor and pleasure. The National Library of Finland Bulletin 2009. http://www.kansalliskirjasto.fi/extra/vanhat_bulletinit/ bulletin09/article8.html, last accessed on 20 Nov 2010.

Krikmann, Arvo 2006. Contemporary Linguistic Theories of Humour. Folklore: Electronic Journal of Folklore, Vol. 33, pp. 28-58.

Krikmann, Arvo 2008. "ATU” jokes: Old and Abandoned. http://haldjas.folklore.ee/ $\sim$ kriku/HUUMOR/KRIKMANN_ATU_ready.pdf, last accessed on 20 Nov 2010.

Krikmann. Arvo 2009. On the Similarity and Distinguishability of Humour and Figurative Speech. Trames, Vol. 13, No.1, pp. 14-40.

Laineste, Liisi 2008. Post-Socialist jokes in Estonia: continuity and change. Dissertationes Folkloristicae Universitatis Tartuensis 12. Tartu: Tartu University Press.

Lipps, Theodor 2010 [1898]. Komik und Humor: Eine psychologisch-ästhetische Untersuchung. Bremen: Europäischer Hochschulverlag.

Raskin, Victor 1985. Semantic Mechanisms of Humor. Dordrecht \& Boston \& Lancaster: D. Reidel Publishing Company.

Veale, Tony 2004. Incongruity in Humour: Root Cause or Epiphenomenon? http:// afflatus.ucd.ie/Papers/fest2004.pdf, last accessed on 20 Nov 2010.

Wirth, Uwe 2001. Abduction, Wit, Stupidity - From Peirce to Freud. http:// www.digitalpeirce.fee.unicamp.br/witwir.htm, temporarily not available. 